\title{
Aneka Fungsi Lopo Dalam Kehidupan Orang Atoin Meto Di Wilayah Kabupaten Timor Tengah Utara
}

\section{Various Functions of Lopo in the Life of the Atoin Meto People In North Central Timor Regency}

\author{
Selsus Terselly Djese, $1^{\mathrm{a}, *}$, Tapin Yohanes $2^{\mathrm{b}}$, \\ a Badan Perencanaan Pembangunan, Penelitian dan Pengembangan Daerah Provinsi NTT \\ ${ }^{\mathrm{b}}$ Universitas Katolik Widya Mandira Kupang \\ *nongdjese@gmail.com \\ Naskah Diterima : 15 Desember 2019; Di-review : 23 Desember 2019; Dimuat: 30 Desember 2019 \\ DOI : \\ Copyright OFLOBAMORA 2019
}

\begin{abstract}
Kajian ini ingin membahas tentang fungsi Lopo dalam kehidupan masyarakat atoin meto pada beberapa wilayah administratif kabupaten Timor Tengah Utara (TTU). Kajian ini menggunakan metode kualitatif interpretatif. Berdasarkan hasil kajian, ditemukan bahwa fungsi lopo dibagi atas tiga kategori yaitu fungsi profan, fungsi sosial dan fungsi sakral. Lopo mempunyai fungsi sakral karena ia berfungsi sebagai tempat penyimpanan bahan makanan, sebagai rumah laki-laki, dan sebagai tempat penyimpanan benih/bibit tanaman. Lopo juga mempunyai fungsi sosial sebagai penanda budaya patriarkat, sebagai media kontak sosial, sebagai lambang kecukupan atau ketersediaan pangan, sebagai penanda identitas dan harga diri dan sebagai perekat sosial antara kerabat keluarga. selanjutnya, Lopo juga mempunyai fungsi sakral sebagai ume, sebagai tempat berdiam yang ilahi dan leluhur atoin meto, sebagai tempat berdiam bahan-bahan makanan dan lopo dalam kesatuannya dengan Ume sebagai lambang kesatuan pria dan wanita dalam ikatan perkawinan.
\end{abstract}

Keywords: Lopo, Atoin Meto, Fungsi, Pertanian, profan, sakral.

\section{Abstrak}

This study wants to discuss about the function of Lopo in the life of the atoin meto in several administrative regions in the district of North Central Timor (TTU). This study uses interpretative qualitative methods. As a results, the study found that lopo has three functions; profane function, social function and sacred function. Lopo has a sacred function because it functions as a storage place for food, as a man's house, and as a storage place for seeds or plant seeds. Lopo also has a social function as a marker of patriarchal culture, as a medium of social contact, as a symbol of the adequacy or availability of food, as a marker of identity and self-esteem and as a social glue. Furthermore, Lopo also has a sacred function as ume, as a homo for the highest and ancestral of atoin meto, as a dwelling place for food ingredients and lopo in its unity with Ume become a symbol of the unity of men and women in marriage.

Keywords: Lopo, Atoin Meto, Function, profane, sacred.

\section{Pendahuluan}

Rumah, dalam banyak kebudayaan; dari yang tradisional hingga yang paling modern, merupakan suatu kesatuan antara beberapa ruang ataupun beberapa bangunan terpisah. Dalam kehidupan modern yang lebih mementingkan keberfungsian dan efisiensi ruang, rumah biasanya terdiri dari satu bangunan tunggal yang mencakup di dalamnya ruang tidur, dapur, garasi, ruang rekreasi dan hiburan, ruang olah raga, dan sebagainya. Akan tetapi dalam kehidupan tradisional, lazimnya rumah merupakan 
istilah untuk menjelaskan kesatuan beberapa bangunan fisik terpisah seperti rumah tinggal, dapur, lumbung, toilet, kandang ternak, pondok dan lainnya. Istilah rumah dengan kesatuan beberapa bangunan fisik ini misalnya dalam ditemukan dalam kehidupan berumah orang atoin meto.

Tentang orang atoin meto, secara etimologis, Sa'u (2004) menerangkan bahwa atoin meto merupakan sebutan untuk sekelompok besar suku di daratan dan pedalaman pulau Timor bagian barat. Secara etimologis, kata Atoin dan Meto, berasal dari kata bahasa Dawan (Uab Meto). Atoin berarti orang dan Meto berarti kering atau tidak ada air. Suku bangsa ini seringkali disebut dengan nama yang berbedabeda. Lazim juga dikenal degan orang dawan. Dawan sebenarnya merupakan sebuah istilah yang diberikan oleh orang Belu di sebelah timur (Lake, 1999:17).

Berdasarkan pembatasan tersebut terdeskripsi secara jelas bahwa istilah atoin meto merujuk pada sekelompok orang yang hidup pada suatu keadaan topografis tertentu. Atoin meto merupakan sekelompok orang yang menetap di suatu daerah yang secara topografis kering, bertanah gersang dan mengalami kesulitan untuk memperoleh air. Mereka juga dikenal dengan nama orang dawan. Secara geografis, orang-orang atoin meto mendiami hampir seluruh pulau Timor bagian Barat Nusa Tenggara Timur. Neonbasu (2016) mencatat bahwa menurut catatan para ahli tentang kawasan Pulau Timor, Suku atoin meto mendiami 10 swapraja (pembagian wilayah zaman akhir penjajahan dan awal kemerdekaan) di Timor Barat. Sepuluh swaparaja ini adalah Biboki, Insana, Miomafo, Amanuban, Amanatun, Mollo, Amarasi, Amfoang, Fatuleu, Kupang dan Ambenu di negara Timor Leste.

Dalam kehidupan berumah sejumlah besar orang atoin meto ini, terutama pada wilayah administrasi kabupaten Timor Tengah Utara, rumah merupakan sebuah kesatuan antara ume atau uem bhubu dan lopo sebagai rumah tempat menetap dan berdiam. Ume dan lopo merupakan dua buah bangunan terpisah yang berada sebagai suatu kesatuan rumah atau tempat kediaman suatu keluarga orang atoin meto. Ume merupakan rumah tempat tinggal dan lopo sebagai tempat penyimpanan bahan makanan atau lumbung dari penghuni rumah tersebut. Posisi lopo yang terpisah dari ume dapat dilihat pada gambar 1 .

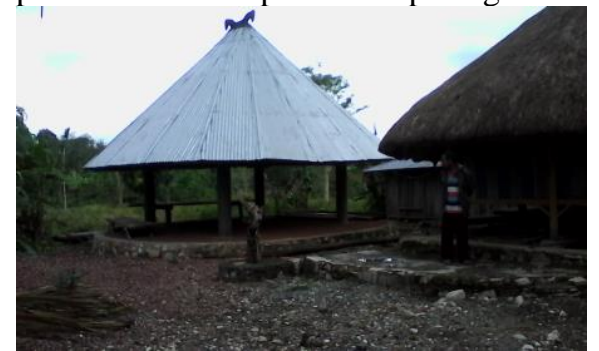

Gambar 1. Salah satu Lopo milik keluarga Taumnais di Loel
Secara historis Sa'u (2010) menjelaskan bahwa pada awal mula, rumah kalangan orang atoin meto disebut dengan nama Ume-Suba. Dalam perkembangan selanjutnya menurut $\mathrm{Sa}^{\prime} \mathrm{u}$ (2010) Ume-Suba' ini dipisahkan dalam dua bangunan terpisah. Ruang bawah dari Ume-Suba' itu rupanya dikembangkan menjadi rumah tinggal anggota keluarga dan segala aktivitas hidupnya. Bangunan ini disebut ume. Sementara ruang atas, yang berfungsi sebagai lumbung, tetap dipertahankan fungsinya tetap diubah bentuknya; dibangun terpisah dari rumah tinggal atau Ume-Suba'. Orang atoin meto menyebutnya lopo atau lumbung.

Realiatas ini merupakan salah satu contoh yang menggambarkan bagaimana setiap ruang dalam rumah, ataupun setiap bangunan dalam kesatuan rumah mempunyai atau menjalankan fungsi secara spesifik dari zaman dahulu hingga kini. Dalam dunia arsitektur, Wahid dan Alamsyah (2013:47-54) merangkum beberapa penjelasan para ahli bangunan tentang fungsi suatu bangunan, termasuk fungsi dari aspek sosial budaya. Di antaranya Broadbent yang menggagas tentang enam fungsi bangunan di antaranya adalah Symbolic Function atau culutral implication.

Berkenaan dengan fungsi ini, menurutnya, bangunan dapat memberikan nilai-nilai simbolik terutama pada kegiatan-kegiatan keagamaan atau yang bernuansa budaya. Selanjutnya Norberg-Schulz yang melihat ada empat fungsi ruangan dalam dunia arsitektur termasuk Social Millieu yang menjadi ekspresi yang dapat mempresentasikan sistem sosial sebagai suatu kesatuan. Dengan kata lain bangunan dapat menghadirkan status sosial pemiliknya dalam suatu sistem sosial budaya tertentu. Ia juga menggagas tentang Cultural Symbolization, yang mana menurutnya arsitektur adalah obyek budaya dan merupakan hasil karya manusia untuk memenuhi kebutuhannya. Melalui simbolisasi budaya, arsitektur membentuk sebagian dari keseluruhan kesinambungan sejarah dan budaya.

Seterusnya ada Ligo yang memunculkan lima fungsi sebuah bangunan, termasuk Social Function yang erat berkaitan dengan konkritisasi dari institusi sosial dan karakteristik yang bernilai dari budaya atau masa tertentu ke dalam bentuk arsitektur tertentu serta Cultural/Existential Function yang berkenaan dengan perwujudan dari nilai-nilai universal atau struktur sunconcious dari spatial dan orientasi psikologis yang lebih berhubungan dengan esensi kemanusiaan dari pada hidup manusia dalam satu kurun waktu dan tempat tertentu.

Dalam perjalanan waktu, fungsi ini mulai mengalami pergeseran. Niracanti (2000) seperti dikutib oleh Hapsari dan Syahbana (2013:171-172) menuliskan tentang pengaruh struktur sosial terhadap pergeseran fungi rumah seperti faktor jenis pekerjaan, tingkat pendapatan, lama tinggal dan status kepemilikan rumah. Di samping itu, seturut 
yang dikutib Hapsari dan Syahbana, (2013:173) dari Danarti, (1996), faktor perjumpaan dan kontak dengan budaya lain dan modernitas juga tidak bisa dilepaskan dari pergeseran fungsi rumah. Fenomena ini terjadi tidak jadi di daerah perkotaan tetapi juga di daerah pedesaan. Pergeseran ini mengancam tergerusnya beragam fungsi rumah yang sejatinya melekat dengan karakter luhur masyarakat yang menjadi acuan sosial dalam bertindak dan bertutur kata. Dengan demikian, penemuan akan fungsi suatu rumah tidak lain juga serentak merupakan penemuan akan karakter luhur masyarakat pembangun dan penghuninya. Kajian dalam tulisan ini dilakukan untuk menganalisis fungsi lopo sebagai salah satu bangunan rumah orang atoin meto di wilayah administrasi kabupaten Timor Tengah Utara. Diharapkan hasil kajian ini dapat menjadi langkah penemuan karakter bangsa yang tersirat dalam wujud kebudayaan fisik khususnya bangunan lopo.

\section{Kerangka Teori}

Kajian ini berpijak pada teoritikus kebudayaan Universal Clyde Kluckhohn dan A. L. Kroeber (dalam Daeng, 2000). Keduanya mengusulkan untuk membedakan secara tajam wujud kebudayaan universal sebagai suatu sistem dari ide-ide dan konsep-konsep, dari wujud kebudayaan sebagai suatu rangkaian tindakan dan aktivitas manusia yang berpola, serta dari wujud kebudayaan sebagai benda hasil kerja manusia itu sendiri. Kebudayaan ideal atau adat-istiadat mengatur dan memberi arti pada tindakan dan karya manusia. Ide-ide dan gagasangagasan serta aktivitas/karya manusia menghasilkan benda-benda fisik. Selanjutnya kebudayaan fisik membentuk suatu lingkungan hidup tertentu yang sering pula mempengaruhi pola-pola perbuatan dan cara berpikir manusia. Dengan bahasa yang lain dapat dikatakan bahwa ketika suatu ide atau gagasan digiatkan menjadi wujud atau rupa tertentu maka ide itu mendapat rupanya dan di dalam rupa itu berdiam ide atau gagasan perupanya.

Bangunan apapun bentuknya tidak lain merupakan wujud kebudayaan universal. Secara konkret suatu bangunan merupakan rupa kebudayaan fisik. Akan tetapi di dalamnya tersirat wujud kebudayaan universal yang meliputi tiga wujud sebagaimana telah dijelaskan. Ia lahir dari berbagai nilai, ide atau gagasan tradisi dalam suatu budaya tertentu. Dengan demikian di baliknya terkandung berbagai nilai, ide, konsep dan gagasan para pendirinya. Ide, konsep dan nilai-nilai luhur tersebut mendapat rupanya melalui teknik-teknik arsitekrut dan ilmu pengetahuan tradisional dan menggunakan bahan yang disediakan alam sekitar pembuatnya. Teknik arsitektur untuk memberi wujud pada ide, gagasan dan pemahaman budaya dalam suatu kurun waktu tertentu tersebut memperoleh rupa dalam suatu stuktur bangunan.

\section{Metode}

Kajian ini dilakukan dengan menggunakan metode kualitatif interpretatif. Seluruh aktivitas yang dilakukan oleh Tobe berkenaan dengan pelaksanaan peran dan fungsinya akan diuraikan, diinterpretasi dan dikategorikan. Teknik interpretasi yang digunakan dalam kajian ini menggunakan metode Semiotika Roland Barthes. Gagasan Barthes ini, dalam semiotika dikenal dengan Order Of Signification yang mencakup denotasi (makna sebenarnya/harafiah/ sesuai kamus) dan konotasi (makna ganda yang lahir dari pengalaman kultural dan personal). Denotasi adalah tingkat pertandaan yang menjelaskan hubungan penanda dan petanda pada realitas, menghasilkan makna eksplisit, langsung, dan pasti. Konotasi adalah tingkat pertandaan yang menjelaskan hubungan penanda dan petanda yang di dalamnya beroperasi makna yang tidak eksplisit, tidak langsung, dan tidak pasti (Kusumarini, 2006).

Hasil interpretasi yang dilakukan oleh penulis dijaga kedekatan otentisitasnya dengan dua hal. Pertama; penulis melibatkan kembali informan untuk membaca dan mengkoreksi hasil interpretasi. Kedua; penulis menggunakan sejumlah referensi terkait tentang topik tulisan yang pernah dilakukan oleh para peneliti sebelumnya sebagai acuan interpretasi. Data primer yang digunakan merupakan data hasil wawancara dengan seorang tetua di Kampung Usapinonot pada bulan Juni 2014, seorang Tobe di kampung Loel, pada bulan Mei 2015 dan April 2016 dan seorang pengobat tradisiaonal di Naen pada bulan Juli 2017.

\section{Hasil dan Pembahasan}

Sebagai sebuah bangunan lumbung, lopo mempunyai beragam fungsi; langsung maupun simbolis, entah secara profan sebagai sebuah bangunan lumbung tempat orang atoin meto menyimpan hasil panenan mereka dan sebagai tempat berdiam para lelaki, juga secara sosial yang berkenaan dengan beragama aktivitas sosio kultural masyarakat, pun pula secara saklar yang erat berkaitan dengan berbagai aktivitas ritual di dalam lopo.

\subsection{Fungsi Profan}

Sebagai sebuah bangunan lumbung, lopo secara langsung berhubungan dengan bahan makanan dan aktivitas hidup sehari-hari yang terjadi/berlangsung di dalamnya. Dalam lingkup berbagai aktivitas profan sehari-hari, lopo berfungsi sebagai: (1) Tempat penyimpanan bahan makanan. Lopo merupakan tempat menyimpan bahan makanan. Sebagaimana telah disinggung sebelumnya, lopo dibangun untuk menjalankan salah satu fungsi ume sebagai tempat penyimpanan bahan makanan. Bahan 
makanan yang disimpan di dalam lopo, diletakan di bagian atas lopo.

Bahan makanan yang lazim disimpan di lopo adalah jagung dan padi. Padi dan jagung disimpan dalam ikatan dengan teknik perhitungan tertentu. Jagung disimpan dengan hitungan masing-masing ikatan berjumlah enam buah yang dinamakan satu Aisaf. Gabungan sepuluh aisaf dinamakan satu kebutu dan tiga kebutu sama dengan satu kuda. Sedangkan untuk padi dihitung sebagai berikut; empat taka sama dengan satu suat, empat suat sama dengan satu blik atau soka. Perhitungan dan pengelompokan seperti ini biasanya dilakukan oleh kaum wanita mengingat hanya wanita yang diperbolehkan masuk ke dalam Lumbung di bagian atas lopo.

(2) lopo sebagai rumah laki-laki. Dalam perkembangan selanjutnya, bangunan baru yang menjalankan fungsinya sebagai lumbung tersebut dihuni oleh kaum lelaki. Dalam tahapan perkembangan peradapan orang atoin meto, mulai ada pembagian tempat beraktivitas berdasarkan jenis kelamin. Kaum wanita termasuk ibu lebih banyak beraktivitas di dalam ume. Sedangkan kaum lelaki lebih sering berada di lopo. Perkembangan ini mulai diduga bertolak dari unsur keamanan dan keselamatan bahan makanan di bagian atas lopo. Pada saat tertentu misalnya pada malam hari, harus ada anggota keluarga yang menjaga lopo. Untuk itu ia harus bermalam di dalam lopo. Kaum lelaki dirasa tepat untuk mengemban tugas tersebut karena secara sosio kultural, dalam konstruksi kebudayaan patriarkat, kaum lelaki memiliki peran yang lebih daripada kaum wanita. Salah satu perannya adalah bertanggung jawab terhadap keselamatan dan keamanan anggota keluarganya dan barang-barang kepunyaan mereka. Budaya patriarkat juga melandasi adanya pembagian peran dalam kebudayaan orang Atoin Meto seturut perbedaan gender. Kaum lelaki adalah kaum pekerja yang bekerja di luar rumah seperti bertani di ladang atau kebun dan atau memelihara ternak seperti sapi, kambing atau kuda di sekitar wilayah kebun atau ladang sedangkan kaum wanita adalah penanggung jawab urusan di dalam rumah.

Berdasarkan pembagian kerja tersebut, hasil dari kegiatan bertani kaum lelaki disimpan di lopo atau lumbung, tepatnya di bagian atas lopo. Dengan demikian kaum lelaki menjadi penghasil bahan makanan yang bertanggung jawab atas keamanan tempat penyimpanan bahan makanan tersebut. Dengan pemahaman seperti ini rupanya secara perlahan-lahan kaum lelaki mulai menempati lopo untuk menjalankan tanggung jawabnya tersebut. Walaupun demikian akses terhadap bahan makanan yang tersimpan di dalamnya hanya diperbolehkan dilakukan oleh kaum wanita atau ibu.

(3) Lopo sebagai tempat penyimpanan benih/bibit tanaman. Berkaitan dengan bahan makanan yang tersimpan di dalam lopo, ada beberapa ritus yang lazim dilakukan oleh atoin meto. Salah satu ucapara tersebut adalah Napoitan Aen Fini-Penfini atau upacara pengambilan benih padi/jagung sebelum ditanam. Dalam kebudayaan atoin meto rupanya Lumbung atau Lopo tidak hanya digunakan sebagai tempat penyimpanan makanan semata. Lopo juga berfungsi sekaligus sebagai tempat penyimpanan bibit tanaman pertanian. Dalam proses penyimpanan bahan makanan setelah panenan, rupanya telah dibuat pembagian antara hasil panenan yang akan digunakan sebagai bahan makanan dan yang akan dijadikan bibit dalam musim taman yang akan datang. Bibit jagung yang disimpan di lopo dapat dilihat pada gambar 2 .

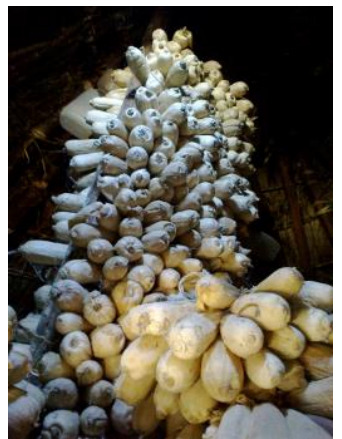

Gambar 2. Ikatan jagung dalam lopo keluarga Leonardus Leu, desa Sengkoen, Usapinonot.

Dalam upacara Napoitan Aen Fini-Penfini atau upacara pengambilan benih padi/jagung sebelum ditanam ada rumusan doa yang dipanjatkan kepada Uis Neno dengan perantaraan para leluhur. Rumusan doa tersebut menyuratkan bahwa ada tindakan pengambilan dan pengeluaran benih. Walaupun tidak secara langsung menyebut tempat penyimpanannya, tetapi mengingat fungsi Lopo dalam kehidupan orang Atoin Meto, sudah dapat dipastikan bahwa benih tersebut di ambil dari dalam Lopo. Loin (2008) menulis rumusan doa ini sebagai berikut; Pah nasi ma ai nasi, neno $i$ he mipoitan pen fini aen fini lof tnao takai he tak penfini-aen fini. Kalimat doa ini berarti; Nenek-Ba'i (Kakek-Nenek), hari ini kami mau mengeluarkan/mengambil benih-benih jagung/padi, sertailah kami agar semua pekerjaan ringan dan berhasil guna.

Upacara selanjutnya adalah ritus Habnin Mnahat atau ritus musim panen. Dalam ritus ini Lopo mendapat tugas peran dan fungsi tersendiri. Peran dan fungsi lopo ini terimplisit dalam rumusan doa yang dikumandangkan dalam ritus tersebut. Loin (2008) mencatat doa tersebut sebagai berikut; $A$ u pen fini ma aenfini he utam ufani neu ume bale, baki tolas penfini aenfini, pena' smanaf ma ane smanaf. Tua-nai bei nasi ma sufaf kauf sin bale. Kalimat dalam doa ini berarti; hasil panen jagung dan padi hendak dikembalikan ke rumah sebagai tempat tinggalnya, tempat penyimpanan benih padi dan jagung, sebagai tempat tinggal nenek moyang, kakek dan nenek. 
Ungkapan kata-kata dalam doa ini menyiratkan bahwa rumah yang dimaksud dalam rumusan doa tersebut tidak lain adalah lopo. Dikatakan demikian karena menurut kebudayaan Atoin Meto, ume dan lopo dipandang sebagai suatu kesatuan sekalipun berbeda bangunan. Keduanya tetap dipandang sebagai kesatuan yaitu rumah. Maka ketika seseorang mengatakan bahwa ia akan bermalam di rumah maka ia akan bermalam di Ume atau di lopo. Sedangkan jika seseorang mengatakan ia akan menyimpan hasil panen di rumah, maka ia akan menyimpannya di lopo. Dengan demikian lopo juga menjadi tempat penyimpanan benih/bibit tanaman.

\subsection{Fungsi Sosial}

Secara sosial, lopo merupakan benda fisik simbolis yang menjalankan fungsinya terutama secara (1) sebagai penanda budaya patriarkat. Pengelompokan bahan makanan ini berlangsung di dalam lopo. Proses perhitungan dan kemudian pengelompokan itu tetap harus diketahui dan disetujui oleh kaum lelaki atau kepala keluarga. Hal ini dapat dilihat dari tempat pelaksanaan kegiatan perhitungan dan pengelompokan tersebut. Kegiatan itu berlangsung di lopo. Lopo sebagai tempat berlangsungnya kegiatan ini menjadi simbol bahwa tindakan menghitung dan mengelompokan bahan makanan berdasarkan perhitungannya harus diketahui dan disetujui atau disahkan oleh kaum lelaki atau kepala keluarga. Walaupun proses pengelompokan dan perhitungan hanya dilakukan oleh kaum wanita, namun karena proses ini berlangsung di lopo maka, lopo menjadi simbol keturutsertaan kaum lelaki dalam proses tersebut. Sebagaimana telah dijelaskan sebelumnya, tindakan menghitung dan mengelompokan bahan makanan berdasarkan perhitungannya harus dikatahui dan disetujui atau disahkan oleh kaum lelaki atau kepala keluarga.

Dalam kebudayaan atoin meto, sebagaimana telah dijelaskan sebelumnya, hanya kaum wanita atau ibu dalam keluarga yang boleh masuk ke dalam lumbung. Oleh karenanya makan bahan makanan yang tersimpan di bagian atas lopo hanya boleh disimpan dan dikeluarkan oleh kaum wanita. Dalam kebiasaan orang atoin meto, sebelum disimpan dan ketika diambil dari dalam lumbung, bahan-bahan makanan harus diletakkan di lantai lopo.

Tindakan seperti ini dapat dipahami sebagai tindakan simbolis. Ia ingin menggambarkan kuatnya budaya patriarkat dalam kebudayaan atoin meto. Setidaknya, keharusan untuk meletakkan bahan makanan di lantai lopo menggambarkan dua makna simbolis. Makna yang pertama; kaharusan untuk meletakan bahan makanan di lantai lopo dapat menggambarkan tindakan penyerahkan kepada kaum lelaki karena lantai lopo adalah wilayah kaum lelaki. Lumbung yang terletak di bagian atas lopo adalah wilayah perempuan akan tetapi lantai lopo atau lopo bagian bawah dan keseluruhan bangunan lopo adalah tempat aktivitas kaum lelaki atau tempat para lelaki. Walaupun kaum wanita yang berhak untuk masuk ke dalam lumbung untuk menyimpan atau mengeluarkan bahan makanan, akan tetapi proses masuk dan keluarnya bahan makanan tersebut harus diserahkan pertama-tama kepada kaum lelaki. Dengan demikian tindakan meletakan di lantai Lopo adalah simbol penyerahan kepada kaum lelaki atau kepala keluarga.

Makna simbolis kedua; tindakan ini dapat pula diartikan dengan tindakan meminta persetujuan kaum lelaki mengingat lopo adalah tanggung jawab para lelaki atau kepala keluarga. Dalam kebudayaan atoin meto kaum lelaki adalah kepala keluarga, penanggung jawab urusan dalam keluarga dan pemimpin keluarga, maka ia tetap bertanggung jawab terhadap bahan makanan yang tersimpan di bagian atas lopo. Menyetujui keluar dan masuknya bahan makan ke dalam lopo merupakan bentuk tanggung jawabnya. Dengan demikian dapat disimpulkan bahwa lopo berfungsi sebagai media penegasan budaya patriarkat dalam kebudayaan atoin meto.

Dalam kebudayaan atoin meto, lopo selalu terletak atau didirikan di depan ume. Ada sebuah alasan yang kiranya dapat menjelaskan mengapa letak lopo selalu berada di depan rumah. Alasan tersebut adalah konstruksi budaya patriarkat dalam kehidupan orang atoin meto. Dalam kebududayaan Patriarkat, lelaki adalah yang pertama. Ia memegang peran penting terlebih dalam hal urusan adat istiadat. Ia menjadi pemimpin keluarga dan pembuat keputusan-keputusan penting. Budaya patriarkat ini juga dianut oleh masyarakat dalam kebudayaan atoin meto. Lopo adalah rumah lelaki dan lelaki adalah dia yang selalu berada di depan, maka bangunan lopo selalu berada di depan ume atau di pekarangan (lihat gambar 3).

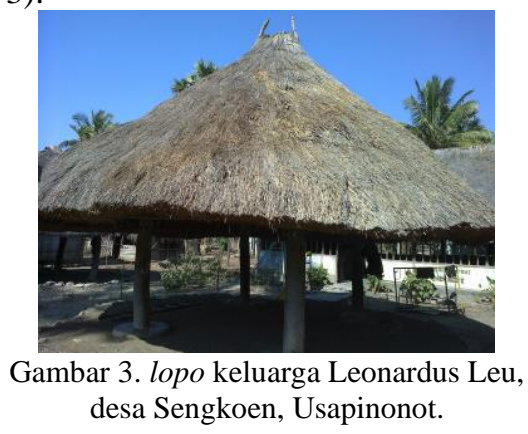

(2) Lopo sebagai media kontak sosial. Lopo juga dijadikan tempat berlangsungnya segala macam urusan yang berhubungan dengan peran lelaki. Konstuksi budaya patriarkat dalam alur hidup atoin meto menegaskan bahwa kaum lelaki berperan sebagai pengambil keputusan dalam berbagai urusan baik urusan keluarga, kemasyarakatan dan urusan penting lainnya. Urusan keluarga dan terlebih permasalahan kemasyarakatan lebih banyak dibicarakan di dalam lopo. Lopo merupakan tempat kaum lelaki duduk dan berbincang. Perbincangan ini 
berkisar antara masalah kemasyarakat dan masalah adat istiadat.

Lopo merupakan tempat menerima tamu laki-laki. Sejalan dengan peran kaum lelaki dalam kebudayaan atoin meto sebagaimana telah dijelaskan di atas, maka untuk urusan tersebut, kaum lelaki bertemu dan berdialog dengan orang lain, pertemuan dan dialog ini kadang terjadi di kebun atau ladang kadang tetapi juga terjadi di rumah. Di rumah, pertemuan itu sering berlangsung di dalam lopo. Lopo merupakan bangunan yang terbuka bagi kaum lelaki. Di dalamnya semua kegiatan yang berhubungan dengan aktivitas kaum lelaki dilakukan. Dengan demikian lopo menjadi media kontak sosial antara kaum lelaki dalam kebudayaan atoin meto. Dengan kata lain dapat disimpulkan bahwa lopo berfungsi sebagai media kontak sosial kaum lelaki.

(3) Lopo sebagai penanda identitas dan harga diri. Dalam kebudayaan atoin meto, seorang pria dan wanita yang telah menikah harus membangun ume dan lopo karena kedua bangunan terebut memiliki makna tersendiri. Sa'u (2010) menjelaskan bahwa, setelah membangun rumah dan lumbung secara fisik, maka dalam perkawinan, sang isteri boleh menerapkan adat istiadat sang suami. Di sana mereka boleh menjalankan tabu tertentu sesuai dengan adat sang suami.

Di sini, lopo dan ume juga merupakan lambang kemampuan dan harga diri seorang lelaki sebagai seorang kepala keluarga. Dalam kebudayaan tradisional orang atoin meto, kemampuan seorang lelaki untuk mendirikan lopo merupakan sebuah bagian dari pengakuan kolektif klan atau sukunya atas kemampuan untuk menghidupi keluarganya. Pendiriaan kedua bangunan tersebut sekaligus merupakan tanda secara adat bahwa isterinya sudah masuk ke dalam klan atau suku dari suaminya. Dengan itu pula isterinya sudah dapat menjalankan tata cara dan pola hidup tertentu, menjalankan ritusritus tertentu dan menghindari pemali tertentu pula menurut norma-norma adat sang suami. Di sini kemampuan sang suami sebagai lelaki dan kepala keluarga dinilai oleh klannya dan masyarakat umumnya.

Kemampuan untuk membangun ume dan lopo juga bermakna bagi masyarakat umumnya. Di hadapan masyarakat, kemampuan suatu keluarga untuk mendirikan rumah; ume dan lopo merupakan suatu tanda kesiapan untuk berumah tangga. Di rumah yang itulah suami dan istrinya dinilai telah mampu untuk hidup mandiri. Mereka telah mampu untuk mengatur segala rencana hidup sehari-hari dan perencanaan masa depan terutama berkaitan dengan kepastian mata pencaharian dan pengaturan konsumsi hidup.

Tanpa rumah; ume dan lopo, seorang lelaki dinilai belum siap untuk secara adat untuk menghidupi isterinya. Tanpanya, sang isteri belum dapat menjalankan adat istiadat dan norma-norma adat sang suami. Tanpa dua bangunan tersebut, seorang lelaki juga dinilai masyarakat belum siap untuk berumah tangga. Oleh masyarakat, mereka dinilai belum mampu untuk mengatur hidupnya terutama berkaitan dengan kepastian mata pencaharian sang kepala keluarga dan pengaturan konsumsi hidup mereka secara mandiri. Di titik inilah harga diri dan identitas lelaki sebagai kepala keluarga dan martabat keluarganya diletakkan.

(3) Lopo sebagai perekat sosial antara kerabat keluarga. Sebagaimana sudah diterangkan sebelumnya bahwa dalam kebudayaan orang atoin meto di wilayah kabupaten TTU, ume dan lopo adalah rumah khas masyarakat yang sudah berlangsung secara turun-temurun. Pembangunan dan kepemilikan ume dan lopo adalah tradisi leluhur yang terus dipelihara oleh setiap anggota orang atoin meto. Sa'u (2010) dalam pengamatannya menulis bahwa, sistem pembuatan dan pembangunan rumah tinggal yang selalu terdiri dari rumah dan lumbung, hal itu menunjukkan suatu pernyataan kesetiaan terhadap sistim hidup yang sudah lama dianut. Kesetiaan terhadap sistem hidup menentukan kelekatan terhadap tradisi leluhur. Kelekatan itu menampakkan kuat ikatan sosial terhadap klan atau suku. Hubungan kekerabatan antara anggota klan yang satu dengan yang lain sungguh terjalin dengan baik karena adanya ikatan sosial yang kuat terhadap tradisi dan normanormanya.

Dalam praksis hidup sehari-hari, orang atoin meto juga akan menghabiskan banyak ativitas dalam rumah; di dalam ume dan lopo. Kaum wanita beraktivitas lebih banyak dan lebih lama di dalam ume sedangkan kaum lelaki di dalam lopo. Salah satu aktivitas itu adalah menerima sanak keluarga dan kerabat jauh yang datang berkunjung. Ume dan lopo merupakan media kontak sosial antar keluarga tersebut. Sebuah keluarga yang datang berkunjung akan diterima di lopo. Selanjutnya kaum lelaki dari keluarga pengunjung akan terus berada di dalam lopo sedangkan kaum perempuan akan beralih ke dalam ume. Kontak sosial antar kerabat dan sanak keluarga akan mempererat ikatan kekerabatan di antara mereka. Ume dan lopo menjadi media pembina ikatan kekerabatan tersebut.

Ikatan tali kekerabatan secara fisik sebagaimana telah digambar ini akan diperkuat secara psikis setelah pihak tuan rumah yang dikunjungi dan pihak tamu atau keluarga yang berkunjung bersatu dalam jamuan makan bersama. Jamuan yang tersaji adalah hasil olahan bahan makanan yang telah disimpan di dalam lopo. Lopo dan bahan makanan yang tersimpan di dalamnya merupakan ikatan psikis yang mempersatukan seluruh anggota keluarga yang memilikinya. Ia menjadi pengikat karena seluruh anggota keluarga yang menyantap hidangan dari lumbung yang satu yang berada di bagian atas lopo. Ikatan ini akan dialami juga oleh pihak keluarga yang berkunjung ketika bersantap bersama dengan 
keluarga pemilik lopo atau keluarga yang dikunjungi. lopo menjadi media pengikatan kekerabatan yang demikian.

(4) Lopo berfungsi sebagai lambang kecukupan atau ketersediaan pangan. Lopo tidak hanya menjadi lumbung makanan yang penyimpan persediaan bahan makanan tetapi juga menjadi tempat penyimpanan bibit atau benih bagi musim tanam di tahun yang akan datang. Topografi wilayah pulau Timor umumnya dan wilayah hunian atoin meto khususnya, yang kering, tandus dan berbatu-batu serta bercurah hujan rendah mengakibatkan dalam waktu satu tahun hanya ada satu kali kesempatan untuk bercocok taman. Untuk itu masyarakat membutuhkan suatu sistem penyimpanan bahan makanan yang menjamin kecukupan dan ketersediaan pangan serentak ketersediaan bibit yang akan ditanam kemudian. Sistem ini terlaksana karena adanya lopo. Di sini kehadiran lopo dilihat sebagai tanda ketersedian dan kecukupan pangan keluarga pemilikinya. Kehadiran lopo adalah kehadiran yang memberi hidup dan menyelamatkan.

Lebih jauh, kehadiran lopo belumlah cukup sebagai tanda ketersediaan dan kecukupan bahan pangan. Yang paling menentukan adalah isi atau kandungan loteng lopo. Semakin banyak isi loteng lopo semakin cukup suatu keluarga ditinjau dari ketersediaan bahan makanan. Sebaliknya semakin sedikit ketersediaan bahan makanan di loteng lopo, semakin kurang nilai suatu kelurga dari sisi ketersediaan bahan pangan.

\subsection{Fungsi Simbolis Sakral}

Secara simbolis, lopo merupakan tidak saja suatu bangunan profan tempat aktivitas rutin sehari-hari, tetapi juga suatu bangunan sakral tempat berlangsungnya berbagai aktivitas ritual. Sebagai suatu bangunan sakral, lopo berfungsi sebagai: (1) sebagai ume. Ruangan di bagian loteng lopo atau bagian atas lopo yang berfungsi sebagai Lumbung diharamkan bagi sembarang orang. Yang boleh mengadakan akses ke dalam lumbung adalah kamu wanita atau ibu rumah tangga dalam keluarga pemilik lopo. Setelah peralihan bentuk dari salah satu ruang dalam ume menjadi bangunan tersendiri, dan kemudian menjadi tempat aktivitas kaum pria, ruangan bagian atas lopo yang berfungsi sebagai lumbung tetap menjadi wilayah aktivitas kaum wanita. Hanya ibu keluarga yang boleh masuk ke dalamnya. Dengan demikian dapat dikatakan bahwa di dalam lopo masih terdapat ume. Sekalipun kaum lelaki yang bertanggung jawab terhadap keamanan dan keselamatan bahan makanan yang tersimpan di dalam lumbung bagian lopo sebagai hasil jerih lelahnya, tetapi ia tidak berhak untuk masuk ke dalamnya.

Kekhususan yang diterima kaum wanita ini rupanya berhubungan maknanya dengan perannya dalam teknik pertanian atoin meto. Kaum wanita mengambil peran penting dalam siklus pertanian kaum atoin meto. Dalam siklus tersebut, terdapat tahap-tahap yang dilalui, mulai dari membuka kebun baru hingga memanen. Adapaun tahap-tahapan tersebut dijabarkan oleh Taum (2008), sebagai berikut; tahap kesatu adalah tahap menebas hutan atau lef nono/tafek hau ana. Tahap kedua merupakan tahap membakar hutan atau polo nopo/sifo nopo, tahap ketiga adalah tahap menanam atau lef boen no'o, tahap keempat adalah tahap pertumbuhan tanaman atau eka ho'e, tahap kelima adalah tahap panenan perdana atau tasana mate dan tahap keenam adalah tahap panenan berakhir atau tnibun bola' if $m a$ aen tauf.

Dalam siklus tersebut, kaum wanita mengambil peran dalam menyediakan bibit, sebelum proses penamanan, menaman atau lef boen no'o dan memetik hasil panenan atau tnibun bola'if ma aen tauf. Perlakukan khusus ini terus berlanjut ketika hasil panenan telah selesai dipetik. Kaum wanita tetap memiliki hak dalam proses penyimpanan, pengolahan dan penyuguhan ataupun pengambilan bahan makanan untuk keperluan tertentu. Perlakuan khusus terhadap kaum wanita sebagaimana telah dideskripsikan di atas dapat dilihat kaitan maknanya dengan pemahaman tradisional tentang keseburun ibu dan ladang. Daeng (2000) menilai bahwa pada masyarakat agraris tradisional, kaum wanita atau ibu selalu dihubungkan dengan kesuburan atau kemampuan untuk melahirkan. Menurutnya wanita ibarat ladang yang akan menghasilkan jika diusahakan. Dengan demikian ladang dan wanita tidak dapat dipisahkan. Kesuburan ladang dipersandingkan dengan kesuburan kaum wanita. Keberhasilan pertanian selalu ditentukan dengan peranan wanita di dalamnya. Jika ladang ingin menghasilkan sesuatu yang baik maka sesungguhnya dibutuhkan peran seorang wanita. Peran kaum wanita ini akan menyata dalam pemilihan dan penyimpanan benih. Benih berhubungan dengan pertumbuhan dan kesuburan agar dapat dipanen. Kenyataan ini berhubungan dengan kesuburan kaum wanita (bdk. Daeng, 2000).

Peranan kaum wanita ini melahirkan berbagai cerita mitos tentang muasal tanaman padi, jagung dan kacang-kacangan di berbagai wilayah. Dalam tradisi pertanian di wilayah Atoin Meto juga terdapat sebuah mitos tentang asal-usul tamanan palawija. Mitos tentang asal-usul tamanam pangan ini serupa dengan mitos tentang Ine Pare atau Dewi Padi dalam kebudayaan orang Ende-Lio dan Sikka di pulau Flores atau Dewi Sri dalam mitologi muasal tanaman padi di pulau Jawa.

Sa'u (2008) dalam tulisannya menceritakan bahwa pada awalnya Uis Neno (wujud tertinggi orang atoin meto) mengutus delapan raja ke bumi. Para raja tersebut adalah Liurai, Sonba'i, Uis Nuban, Nai lasi, Nai Benu, Nai Fo'an, Nai Bolu Tubah dan Nai Saun Tanas. Delapan raja ini kemudian diceritakan akan bertani, namun mereka belum 
memiliki benih untuk ditabur. Oleh kerena itu mereka meminta benih tersebut kepada Uis Neno. Alih-alih memberikan benih, Uis Neno menghadiahkan mereka seorang wanita. Atas perintah Uis Neno wanita itu dinikahi oleh raja yang sulung yaitu Luirai. Dari hasil pernikahan itu lahirlah seorang anak gadis. Masih menurut perintah Uis Neno, Luirai harus mengurbankan anak gadisnya itu. Dagingnya harus dicincang dan disebarkan di ladang pertanian. Tepat setelah hari ketujuh di atas ladang tempat di mana tubuh anak gadis itu ditabur, tumbuh padi, jagung, kacang-kacangan dan berbagai jenis umbi-umbian.

Peran seorang wanita dalam pertanian dan kesuburannya sebagaimana telah dikemukakan di atas berkiatan dengan lopo. Dalam kebudayaan atoin meto hanya kaum wanita yang boleh mengatur bahan makanan dan perbenihan yang tersimpan di bagian atas lopo. Kekhususan ini berhubungan dengan pandangan tentang kesuburan lahan dengan kesuburan kaum wanita dan peran kaum wanita dalam pertanian sebagaimana dijelaskan oleh Daeng (2000). Sebaliknya kaum lelaki dipandang sebagai yang akan membawa kerusakan dan hama bagi bahan makan yang tersimpan di lopo.

(2) Lopo sebagai tempat berdiam yang ilahi dan leluhur atoin meto. Selanjutnya, selain sebagai menyimpan bahan makanan dan tempat penyimpanan bibit atau benih yang akan digunakan dalam musim taman yang akan datang sebagaimana telah dijelaskan sebelumnya, lopo juga mendapat peran dan fungsi lain. Ia menjadi tempat tinggal nenek moyang; kakek dan nenek orang atoin meto.

Loin (2008) mencatat sepenggal doa dalam ritus.......berkaitan dengan hal ini sebagai berikut; $A u$ pen fini ma aenfini he utam ufani neu ume bale, baki tolas penfini aenfini, pena' smanaf ma ane smanaf. Tua-nai bei nasi ma sufaf kauf sin bale. Kalimat dalam doa ini berarti; hasil panen jagung dan padi hendak dikembalikan ke rumah sebagai tempat tinggalnya, tempat penyimpanan benih padi dan jagung, sebagai tempat tinggal nenek moyang, kakek dan nenek. Loin (2008) menilai bahwa rumusan doa ini menyiratkan suatu permohonan dalam nada mengundang padi dan jagung yang telah makan dan siap dipanen agar berkenan kembali ke tempatnya. Padi dan jagung yang berasal dari rumah (ume bale) dimohon agar berkenan kembali ke rumah. Di sini nampak ada siklus perjalanan dari rumah kembali ke rumah, dari benih kembali ke benih dan bakal makanan. Siklus perjalanan ini dianggap sebagai perjalanan yang sakral. Dianggap perjalanan yang sakral karena menurut Loin (2008) padi dan jagung diyakini sebagai jelmaan cinta Wujud Tertinggi dan nenek moyang atoin meto. Cinta Wujud Tertinggi dan nenek moyang atoin meto tersebut merupa dalam wujud padi dan jagung. Padi dan jagung tersebut merupakan makanan pokok masyarakat atoin meto, dan rumah yang merupakan tempat penyimpanannya adalah lopo. Lopo dan ume merupakan suatu kesatuan pengertian sebagai rumah. Mengingat fungsi dasar lopo sebagai lumbung makanan maka sudah pasti bahwa hasil penenan; padi dan atau jagung disimpan di lopo.

Ungkapan cinta wujud tertinggi dan nenek moyang atoin meto ini disambut dengan menyimpan dan menyantap padi dan jagung tersebut sebagai makanan pokok mereka. Bukti cinta yang menyata dalam rupa padi dan jagung disimpan dalam lopo. Lopo menjalankan peran dan fungsinya sebagai tempat berdiamnya rupa cinta Wujud Tertinggi dan leluhur atoin meto. Lopo terutama lotengnya merupakan tempat yang secara khusus disaklarkan karena hal tersebut. Dalam kehidupan masyarakat agraris tradisional bahan makanan adalah wujud atau jelmaan dari Yang Ilahi. Dengan demikian lopo merupakan tempat rupa Yang Ilahi mengambil tempat untuk berdiam bersama manusia. Kehadiran dan jelmaan Ilahi merupakan berkat dan rahmat bagi manusia. Dengan demikian ketersediaan bahan makanan sejatinya serentak merupakan ketersediaan rupa Sang Ilahi. Ketersediaan bahan makanan merupakan kelimpahan berkat dan rahmat Sang Ilahi. Lopo mengambil peran sebagai media perantara antara manusia dan rahmat Ilahi tersebut. ketersediaan bahan makanan dalam lopo adalah kehadiran sang Khalik dalam rupa kelimpanan berkat dan rahmat.

Bahan makanan adalah rupa yang Ilahi dalam kebudayaan orang atoin meto, seperti juga masyarakat agraris tradisional lainnya. Makanya ia dijunjung tinggi. Lopo menjadi tempat rupa Yang Ilahi itu bersemanyam berada di depan Ume dan tempat bahan makanan sebagai rupa Yang Ilahi itu berada di bagian atas lopo atau Loteng lopo. Letak ini adalah suatu bentuk peninggian, karena dalam pemahaman masyarakat, yang Ilahi selalu berada atau bertahta di atas, di tempat yang tinggi.

(3) Lopo sebagai tempat berdiam bahan-bahan makanan. Peran dan fungsi lopo yang serupa juga terjadi dalam ritus Polen Niki atau membangun benteng pertahanan dan ritus Nunu Nahe/Tnunu Nahe atau pesta Syukur. Lopo atau lumbung tidak saja berfungsi sebagai tempat menyimpan bahan makanan seperti pada dan jagung. Ia juga menjadi tempat berdiamnya roh atau jiwa dari bahan makan tersebut. Dengan kata lain lopo bukan lagi menjadi tempat untuk menyimpan bahan makanan, lebih dari itu ia sebenarnya menjadi tempat tinggal bagi bahan makanan tersebut. Pemahaman ini bertolak dari keyakinan orang atoin meto termasuk di Biboki, bahwa padi dan jagung memiliki roh atau jiwa. Pandangan yang bersifat animistis merupakan gelaja umum dalam hampir semua kebudayaan kuno di dunia. Keyakinan seperti ini tersirat dari ritus dalam tradisi memanen oleh masyarakat setempat. Pada musim panen ada tiga ritus yang dibuat oleh orang atoin meto daerah Biboki sebagaimana dijelaskan 
oleh Timo (2008) yaitu Tlef ane Smanaf, Ta'bena'nahe dan Tnunu' nahe.

Dalam ketiga ritus panenan tersebut padi dan jagung tidak dilihat sebagai benda fisik semata. Lebih dari itu, ia diyakini sebagai benda hidup yang memiliki roh atau jiwa. Keyakinan ini tergambar dalam ritus Tlef ane Smanaf. Secara harafiah, Tlef ane Smanaf berarti memotong jiwa padi. Pelaksanaan ritus ini bertujuan untuk menyelamatkan jiwa padi sebelum dipotong. Masyarakat setempat mempunyai kebiasaan khusus dalam usaha penyelamatan tersebut. Usaha ini dilakukan secara simbolis dengan memotong beberapa batang padi atau jagung dan meletakkannya di atas Ainuan. Dengan itu diyakini bahwa jiwa padi atau jagung tetap menetap di dalam ladang atau kebun dan hasil panenan tidak akan berkurang dan akan memuaskan.

Selain itu ada juga ritus lain yaitu Tnunu' nahe yang secara leksikal berarti gulung tikar. Ritus ini dilakukan setelah ritus Ta'bena' nahe atau membentang tikar untuk merontok atau melepaskan butir-butir padi. Upacara ini bertujuan untuk mengucap syukur atas panenan yang telah didapat, sebagai simbol acara pamitan terhadap para leluhur yang telah menjaga kebun dan untuk menyimbolkan bahwa hasil panenan akan dijaga dengan baik di dalam sokal atau $k a$ 'u.

Dalam ritus ini orang atoin meto daerah Biboki ingin mengatakan bahwa jiwa padi yang masih ada di sawah akan segera diisi ke dalam sokal dan di bawah ke rumah. Sebagaimana telah dijelaskan sebelumnya, dalam pemahaman orang Atoin Meto, rumah selalu berarti ume dan lopo, rumah tinggal dan lumbungnya. Dengan demikian ketika mereka mengatakan jiwa padi yang masih ada di sawah akan dibawah ke rumah maka maksudnya adalah dibawah dan disimpan di lopo. Pemahaman ini menyebabkan peran dan fungsi lopo bukan lagi sebagai tempat untuk menyimpan padi tetapi sebagai tempat tinggal padi. Di dalam lopo bahan makanan berdiam.

(4) Lopo dalam kesatuannya dengan ume sebagai lambang kesatuan pria dan wanita dalam perkawinan. Keberadaan lopo tidak dapat dipisahkan dari ume. Walaupun dalam bentuk yang terpisah dan mempunyai fungsi yang berbeda, keduanya merupakan rumah dalam kebudayaan atoin meto. Ume adalah tempat tinggal dan lopo merupakan lumbung makanannya. Lopo tidak dapat berdiri sendiri walaupun Ume tidak seharusnya memiliki lopo karena lopo lahir dari Ume. Lopo merupakan pemisahan ruangan yang ada di dalam ume. Dalam kebudayaan orang atoin meto, ume dan lopo adalah satu kesatuan yang disebut rumah.

Dari segi fisik, jika lopo merupakan bangunan terbuka dan lebih banyak digunakan oleh kaum lelaki untuk melaksanakan aktivitasnya, maka ume berbentuk tertutup dan secara khusus merupakan tempat kaum wanita. Dengan demikian, ume merupakan tempat berlangsungnya aktivitas kaum wanita, atau aktivitas rumah tangga sebagai seorang ibu dan atau seorang istri beserta anak-anak perempuan. Peranan wanita atoin meto pada umumnya adalah sebagai ibu rumah tangga yang bertugas untuk mengasuh dan membesarkan anakanaknya setelah melahirkannya, menyiapkan dan menyediakan makanan setiap hari, serta memberikan pakaian atau menenun kain sarung dan selimut bagi anggota keluarganya yang lain. Berpijak pada pemahaman ini maka, ume berfungsi sebagai tempat berlangsungnya segala aktivitas kewanitaan tersebut di atas.

Ume menjadi tempat kaum wanita mengasuh anak-anaknya setelah melahirkannya. Dalam kebudayaan atoin meto dahulu kala, para wanita melahirkan anak-anaknya di dalam Ume. Anak-anak tersebut kemudian dibesarkan di dalam ume. Anakanak selalu bersama ibu mereka hingga para waktu usia tertentu, anak-anak lelaki yang telah mencapai usia tertentu mulai keluar dari Ume dan bergabung dengan ayahnya dan kaum lelaki lainnya di lopo. Anak lelaki dan perempuan yang telah dewasa namun belum menikah tidak diizinkan untuk mendirikan sebuah rumah yaitu ume dan lopo. Ia harus tetap tinggal bersama orangtuanya karena ia masih merupakan tanggung jawab orangtuanya hingga ia menikah kelak. Lelaki dan perempuan dewasa harus mengikuti, memperlajari dan melibatkan diri dalam kebiasaan dan rutinitas kedua orangtuanya.

Anak lelaki dewasa akan mengikuti ayahnya berkebun, bercocok taman dan merawat kebun dan memelihara ternak di laur rumah. Di samping itu, anak lelaki juga akan diajak ayahnya mengikuti sejumlah aktivitas sosial di luar rumah. Misalnya menghadiri sejumlah urusan adat istiadat suku mereka. Mereka akan lebih banyak menghabiskan waktunya di lopo bersama ayah dan kamu lelaki lainnya. Berbeda dengan anak lelaki, anak wanita akan senantiasa bersama ibunya. Mereka akan belajar meracik, meramu dan memasak serta menghidangkan makanan. Lebih lanjut, mereka juga belajar menenun dan mengerjakan tugas-tugas seorang ibu lainnya berkaitan dengan urusan rumah tangga. Semuanya dilakukan di dalam ume. Kesiapan dan kecakapan mereka untuk melakukan tugas-tugas seorang ayah dan atau ibunya tersebut menjadi salah satu syarat kedewasaan dan kesiapan untuk berumahtangga. Rupanya kebiasaan ini yaitu pembagian aktivitas berdasarkan gender, tetap berjalan sekalipun pada zaman sekarang anak-anak usia sekolah pada orang atoin meto, umumnya sudah bersekolah.

Dalam kebudayaan tradisional atoin meto, wanita bertugas untuk menyiapkan kebutuhan makan dan minum bagi penghuni rumah yang lain. Tugas ini dilangsungkan di dalam ume karena di dalam ume terdapat ruangan yang berfungsi sebagai dapur, di dalam lopo tidak. Dalam kebudayaan atoin meto, rupanya kaum lelaki dan perempuan tidak berkumpul 
untuk makan bersama. Kaum wanita menyiapkan segala sesuatu di ume, sebelum menghidangkannya kepada kaum laki-laki di dalam lopo. Lazimnya kaum lelaki menggunakan lopo sebagai tempat mereka berkumpul untuk makan bersama sedangkan kaum wanita akan makan di Ume setelah kaum lelaki selesai makan. Rupanya budaya patriarkat sangat terasa dalam kebudayaan atoin meto.

Lebih lanjut, kebudayaan tradisional atoin meto mengharuskan kaum wanitanya untuk menenum. Kecakapan dalam menenum merupakan simbol kemampuan untuk memberikan pakaian bagi anggota keluarga yang lain. Kecakapan ini harus dimilliki oleh seorang wanita karena dalam kebudayaan atoin meto seorang wanita dan atau ibu bertugas/berkewajiban untuk memberi pakaian kepada anggota keluarga inti yang lain. Kaum lelaki tidak pernah terlibat dalam aktivitas ini. Kegiatan menenun ini juga sejatinya dilakukan di dalam ume walaupun dalam perkembangannya kegiatan memenun juga biasa dilakukan di lopo.

Selain fungsi sebagaimana telah disebutkan di atas, ume menjadi tempat tidur kaum wanita di siang dan terutama di malam hari. Fungsi ini didasari oleh bentuk ume yang didindingi secara penuh dan berpintu satu. Stuktur ini diyakini mampu memberikan perlindungan, keamanan, kenyamanan bagi penghuninya. Kaum lelaki dalam kebudayaan atoin meto tidak lazim untuk tidur di dalam Ume. Mereka akan memempati lopo. Pembagian seperti ini didasari oleh keyakinan atau pemahaman tentang kaum lelaki sebagai dia yang harus melindungi dan bertanggung jawab terhadap keluarganya. Peran kaum lelaki ini dijalankan dengan menjadikan lopo sebagai tempat beristirahat di malam hari. Peran kaum lelaki juga diwujudkan dengan menempatkan kaum wanita untuk beristirahat di ume yang secara fisik aman dan nyaman.

Selanjutnya, dalam tata krama tradisional kelompok tertentu orang atoin meto, para wanita hanya dapat menerima tamunya di dalam ume, bukannya di dalam ruang terbuka di dalam lopo. Dalam kebudayaan atoin meto, kaum wanita hanya menerima tamu wanita. Dapat dipastikan bahwa urusan yang berkaitan dengan tamu tersebut adalah juga urusan kewanitaan dan kehidupan sehari-hari mereka. Ruangan tempat pertemuan itu adalah ada di dalam ume. Kepastian urusan kewanitaan ini didasari oleh kebiasaan dalam kebudayaan atoin meto. Kaum wanita dalam kebudayaan atoin meto menangani urusan rumah tangga dan kegiatan di dalam rumah sebagaimana telah dijelaskan sebelumnya. Sedangkan kaum pria mengatur urusan-urusan di luar rumah seperti bertani, beternak, berelasi dengan urusan-urusan kampung tempat tinggalnya dan bertanggung jawab terhadap keluarganya.

Dalam kebudayaan tradisional terdapat pembedaan aktivitas berdasarkan gender. Perempuan terpisah dari lelaki berdasarkan aktivitasnya.
Pemisahankan lopo dari ume, Rumah dari Lumbungnya secara tidak langsung mengafirmasi adanya pemisahakan aktivitas secara gender tersebut. Lelaki akan menempati lopo sedangkan kaum wanita akan menggunakan ume. Sekalipun demikian, ume dan lopo merupakan suatu kesatuan yang tidak terpisahkan. Keduanya adalah rumah bagi orang atoin meto. Maka keduanya dapat disimbolkan dengan perkawinan yaitu simbol persatuan pria dan wanita dalam ikatan perkawinan. Persatuan Ume dan Lopo; rumah dan lumbungnnya adalah persatuan pria dan wanita; suami dan istrinya. Sa'u (2010) menilai bahwa keduanya, ume dan lopo, menjadi simbol kehidupan keluarga, yang mengandung sebuah sistem yang baku dan mantap.

Rupanya paham tentang kesatuan dan pembedaan seperti ini bukanlah sebuah pikiran baru dalam kebudayaan Atoin Meto. Sa'u (2010) menuturkan bahwa paham seperti ini merupakan pandangan khas orang Atoin Meto, yang selalu hidup dalam prinsip dualitas komplementaris. Mereka hidup dalam berbagai hal yang saling bertentangan tetapi tetap satu tak terpisahkan. Paham tersebut menyata dalam pemahaman mereka tentang; manusia yang terdiri dari wanita (feto) dan laki-laki (mone), tentang malam dan siang, lemah lembut dan kekerasan, kiri dan kanan, dalam dan luar, dan sebagainya.

Prinsip dualisme yang saling melengkapi dalam kehidupan Atoin Meto ini oleh Valens Boy (2013), dalam tulisannya disebut sistem 'Duaan.' Menurutnya, dengan mengambil contoh orang atoin meto di daerah Biboki, sistem 'Duaan' ini sama halnya dengan filosofi China tenang Yin dan Yan yang berbeda tetapi saling melengkapi. Demikan halnya dengan sistem Duaan dalam kehidupan Atoin Meto di Biboki. Ada kesatuan antara wanita dan pria atau Feto-Mone, adik kakak atau Olif-tataf, dan sebagainya. Sistem Duaan yang membentuk masyarakat Biboki ini, menurut Valens Boy (2013) sebenarnya bersumber pada dimensi sosial manusia dan terutama pada 'persentuhannya' dengan tata kosmos dan polaritas kosmos yang selalu mempunyai dua sisi berlawanan. Lebih lanjut, ia menerangkan bahwa masyarakat atoin meto di Biboki memilih pola 'wanita/betina-laki-laki/jantan karena inilah salah satu perwujudan polaritas kosmos yang kendatipun saling berlawanan tetapi saling melengkapi.

Pemahaman seperti ini, dalam kebudayaan atoin meto, oleh Cunningham (1966) sebagaimana dikutip Sa'u (2010), disebut sebagai 'kesatuan sekaligus pembedaan' atau unity and difference. Dalam pemahaman atoin meto, yang dimaksudkan dengan kesatuan atau persatuan (unity) adalah bahwa setiap rumah tangga atau keluarga terdiri dari suami istri dan anak-anak, laki-laki dan perempuan; ketiganya membentuk satu kesatuan yang tidak bisa dipisahkan begitu saja, walaupun mereka dibedakan berdasarkan fungsi dan perannya masing-masing. Pihak wanita mengambil alih berbagai urusan di dalam rumah 
tangga yang biasanya terjadi di ume. Sedangkan pihak laki-laki memusatkan perhatiannya dengan urusan-urusan di luar rumah atau di dalam kelompok masyarakat sosial, yang biasanya menggunakan Lopo sebagai medianya. Demikianlah lopo dan ume hadir sebagai suatu perbedaan yang saling melengkapi. Keduanya merupakan suatu kesatuan yang disebut rumah seperti halnya seorang lelaki dan perempuan yang telah menikah merupakan satu kesatuan yang disebut keluarga.

\section{Kesimpulan}

Dalam kebudayaan atoin meto, lopo mempunyai fungsi tertentu. Lopo yang berbentuk bulat dengan atap berbentuk kubah kerucut atau elips seperti bentuk sarang tawon mempunyai tiga fungsi utama yaitu fungsi profan yang meliputi peran lopo sebagai tempat penyimpanan bahan makanan, sebagai rumah laki-laki, dan sebagai tempat penyimpanan benih/bibit tanaman. Selanjutnya secara sosial simbolis, lopo juga berfungsi sebagai penanda budaya patriarkat, sebagai media kontak sosial, sebagai lambang kecukupan atau ketersediaan pangan, penanda identitas dan harga diri dan sebagai perekat sosial antara kerabat keluarga. Sedangkan sebagai bangunan tempat dilaksanakan beberapa ritual, lopo juga secara simbolis menjalankan fungsi Simbolis Saklal sebagai ume, sebagai tempat berdiam yang ilahi dan leluhur atoin meto dan sebagai tempat berdiam bahan-bahan makanan, serta dalam kesatuannya dengan ume sebagai lambang kesatuan pria dan wanita dalam perkawinan.

\section{Referensi}

Cunningham, Clark E. (1966). Soba: an Atoni Village in West-Timor, dalam Koentjaraningrat (ed.) Villages Communities in modern Indonesia. Ithaca: Cornell University Press.

Daeng, Hans J. (2000). Manusia, Kebudayaan dan Lingkungan Tinjauan Antropologis, Yogyakarta: Pustaka Pelajar.

Doredae, Ansel. (1995). Sejarah Budaya Indonesia (ms). Maumere: Sekolah Tinggi Filsafat Katolik Ledalero.

Hapsari, Amierul dan Joesron Alie Syahbana. (2013). Pergeseran Fungsi Rumah Di Kampung Kauman Semarang, Jurnal Teknik PWK Volume 2 Nomor 12013.

Kusumarini, Yusita. (2006). Teori Semiotic. Surabaya: Universitas Kristen Petra.

Lake, Primus. (1999). Sifon: Antara Tradisi dan Risiko Penularan PMS. Yogyakarta: Pusat Penelitian Kependudukan Universitas Gadjah Mada.

Loin, John. (2008). Menyimak Kultus Berladang Orang Dawan pada Masyarakat Suku Loin, TTU.
Cendana, Buletin Fraters SVD Timor, Nomor 10 Juli 2008.

Mubyarto, dkk. (1991). Etos kerja dan Kohesi Sosial Masyarakat Sumba, Rote, Sabu dan Timor Propinsi Nusa Tenggara Timur. Yogyakarta: P3PK UGM.

Neonbasu, Gregor. (2016). Citra Manusia Berbudaya Sebuah Monografi Tentang Timor Dalam Perspektif Melanesia. Jakarta: Antara Publishing.

Sa'u, Andreas Tefa. (2004) Di bawah Naungan Gunung Mutis. Ende: Penerbit Nusa Indah Ende. (2008) Asal-Usul Bibit Tanaman Palawija (Sebuah Mitos dari Atoin Pah Meto). Cendana, Buletin Fraters SVD Timor, Nomor 10 Juli 2008.

---------. (2010) Ume dan Lopo Konsep Tentang Sistem Kehidupan Masyarakat Atoin Meto (Sebuah Catatan Etnohistoris). Cendana, Buletin Fraters SVD Timor, Nomor 12 Juli 2010.

Taum, Yoseph Yapi. (2008). Tradisi Fua Pah: Ritus dan Mitos Agraris Masyarakat Dawan di Timor (Fua Pah Tradition: Agricultural Rite and Myth of Dawanese of Timor Island), Institute of Indonesia Tenggara Studies (East Nusa Tenggara Studies) IITS Publications, Working Paper, dalam http://www.ntt-academia.org/WP4-Pah-AntoniTimor-2008.pdf, diakses 21 Maret 2014.

Timo, John. (2008). Orang Biboki dan Ritus Persawahan, dalam Ritus-Ritus Pertanian, Cendana, Buletin Fraters SVD Timor, Nomor 10 Juli 2008 .

Valens Boy, M. (2013). Pemikiran Dualistis-Kosmis Masyarakat Biboki-Atoin Meto dalam: Gregor Neonbasu, (ed.), Kebudayaan: Sebuah Agenda dalam Bingkai Pulau Timor dan Sekitarnya, Jakarta: Gramedia Pustaka Utama.

Wahid, Julaihi dan Bhakti Alamsyah. (2013). Teori Arsitektur Suatu Kajian Perbedaan Pemahaman Teori Barat dan Timur, Yogyakarta: Graha Ilmu. 